\title{
Industrial tomato for fresh consumption: a technical and economically viable alternative
}

\author{
Daianna Pereira Costa ${ }^{1}$, Juliana Nascimento da Silva ${ }^{1}$, Donielsin da Silva Assunção ${ }^{1}$, Fritz \\ Mohn Penteado ${ }^{1}$, Abadia dos Reis Nascimento ${ }^{1}$
}

${ }^{1}$ Universidade Federal de Goiás, Campus Samambaia, Goiânia, Goiás, Brasil. E-mail: daiannaagronoma@ gmail.com, agronomia125@gmail.com,donielsin@gmail.com, fritzmp@hotmail.com, abadiadosreis@ufg.br

Received: 05/08/2019; Accepted: 20/05/2020.

\section{ABSTRACT}

The cultivation of hybrid tomatoes, intended for fresh consumption, with a determined growth habit, and without support, is an alternative that has a lower production cost. The research aimed to evaluate the productivity and economic viability of different tomato genotypes, with a determinate and indeterminate growth habit. The experimental design was in completely randomized blocks. Ten hybrids and a variety were grown in 2016, and nine hybrids, and a variety in 2018, with a spacing of 0.5 meters between plants. Harvests were carried out in four periods in 2016, at 72, 82, 97, and 105 days after transplanting (DAT); and in 2018 at 81, 87, 97, and 111 DAT. After harvesting, the gross value of production and profit were quantified. The hybrids that obtained the highest production per plant in 2016 were Gabrielle (6,010 kg), with support; Thaise (5.529 kg); and N901 (5.003 kg). In 2018, Dominador and Thaise hybrids had the highest production, with 4.109 and $3.961 \mathrm{~kg}$ per plant, respectively. The gross value of tomato production in 2016 was higher than in 2018 for all hybrids and variety, except for Dominador hybrid. Hybrids with a determined growth habit and conducted without support are a profitable alternative to produce tomatoes intended for fresh consumption, especially the hybrid Gabrielle, which had the highest production. The economic viability of hybrids grown without support is superior to all hybrids with support.

Keywords: Solanum lycopersicum, production, profit.

\section{Tomate industrial para consumo in natura: uma alternativa técnica e economicamente viável}

\section{RESUMO}

O cultivo de tomates híbridos, destinados ao consumo in natura, com hábito de crescimento determinado e conduzidos de forma rasteira, é uma alternativa que apresenta menor custo de produção. O objetivo da pesquisa foi avaliar a produtividade e viabilidade econômica de diferentes genótipos de tomate, com hábito de crescimento determinado e indeterminado. O delineamento experimental foi em blocos inteiramente casualizados, onde foram cultivados dez híbridos e uma variedade em 2016 e nove híbridos e uma variedade em 2018, com espaçamento de 0,5 metros entre plantas. As colheitas foram realizadas em quatro períodos em 2016, com 72, 82, 97 e 105 dias após o transplantio; e em 2018 aos 81, 87, 97 e 111 dias, respectivamente. Após a colheita, foi quantificado o valor bruto de produção e o lucro. Os híbridos que obtiveram maior produção por planta no ano de 2016 foram Gabrielle, cultivo rasteiro, com 6,010 kg; Thaise, com 5,529 kg; e N901, com 5,003 kg. Já em 2018, foram os híbridos Dominador e Thaise, com 4,109 e 3,961 kg por planta, respectivamente. O valor bruto da produção de tomate em 2016 foi superior ao ano de 2018 para todos os híbridos e variedades, exceto para o híbrido Dominador. Híbridos com hábito de crescimento determinado e conduzidos sem tutor são uma alternativa lucrativa para a produção de tomate destinado ao consumo in natura, destacando-se o híbrido Gabrielle, que apresentou a maior produção. A viabilidade econômica dos híbridos cultivados sem tutor é superior a todos os híbridos tutorados.

Palavras-chave: Solanum lycopersicum, produção, lucro. 


\section{Introduction}

The tomato (Solanum lycopersicum L.) is a vegetable of world importance in constant growth; its production was, in the last decade, $157 \%$ higher than that of the beginning of the 1980s (FAOSTAT, 2018). Nationally, the main destination of tomato fruit has been industrial processing for making sauces and pastes, and for this purpose, most plants have a determined growth habit. About fruits produced for fresh consumption, most plants have an indeterminate growth habit, popularly known as table-tomato (Alvarenga et al., 2013).

Tomato is a perennial plant, with an indeterminate growth habit, due to the presence of the dominant SelfPruning (SP) allele (Lifschitz et al., 2014; Rick, 1978; Zsogon et al., 2017). The determined growth habit is justified due to the presence of the recessive self-pruning $(s p)$ mutation, which appeared spontaneously in some plants, around 1914 in the USA, in the state of Florida (Rick, 1978). From this period, there was an increase in studies with plants carrying the $s p$. mutation. This mutation was soon mapped on chromosome six, whose allele in recessive homozygosis causes "self-pruning", which generates the plant's inability to continue forming vegetative branches after flowering (Lifschitz et al., 2014; Pnueli, 1998), thus, characterizing plants favorable for use without support, which stimulates large-scale production used in industrial processing (Filgueira, 2003; Zsogon et al., 2017).

One of the obstacles in the production of table-tomato is the production cost, mainly associated with the increased demand for labor, related to the crop management (pruning, fruit thinning, plant conduction, and removal of old leaves to reducing the incidence of leaf diseases) and phytosanitary treatments (Piotto and Peres, 2012; Navarrete and Jeannequin, 2000). The production cost of one hectare of table-tomato is greater than $100 \%$ of the production cost of the tomato for industrial processing with a proportional area. Although table-tomato has a selling price per ton higher than the industrial tomato, the profit is not always positive due to the production cost (IFAG, 2018).

The variation in the profitability of the producer is the main influence of the supply of fruits in the next harvest (Pagliuca, 2017). In these subsequent harvests, when the supply of table tomatoes is lower, there is an increase in prices charged by the market. Thus, given the reduced supply of tomatoes for fresh consumption and high prices, it is common that the industrial tomato is sold as fruit for fresh consumption. The supply of fruits for processing, sold for fresh consumption, stimulates changes in the seasonal pattern of table-tomato prices (Margarido et al., 1994).

The alternative to produce tomatoes intended for fresh consumption is the cultivate hybrids with a determined growth habit. When cultivated without support, the production cost is significantly lower, in which the use of mulching has been associated. The soil cover avoids the contact of the fruits with the soil, helping in the phytosanitary control and production of clean fruits (Factor et al., 2009).

It is possible to use hybrids with a determined growth habit to reduce the production cost of tomatoes intended for fresh consumption. The research aimed to investigate the productivity and economic viability of different tomato genotypes, with a determined and indeterminate growth habit.

\section{Material and Methods}

\subsection{Description of the experimental area and genotypes}

Two experiments were carried out in Goiânia-GO (16 $35^{\prime} 12$ "S, 49 $21^{\prime} 14^{\prime \prime} \mathrm{W}$, at 730 m altitude) in the years 2016 (May to September, autumn-winter) and 2018 (January to June, summer-autumn).

The climate of the region is tropical warm and rainy (Aw), with a rainy season between October and March, and dry season between April and September. The average maximum temperature from May to September in 2016 was $32.08{ }^{\circ} \mathrm{C}$, and the average for the same period of relative air humidity was $56.4 \%$. In 2018 , for the period from January to May, the average maximum temperature was $30.08{ }^{\circ} \mathrm{C}$, and the average relative air humidity was $65.44 \%$ (UFG/EA, 2018).

The experimental design in 2016 (autumn-winter) was randomized blocks (DBC), with 13 genotypes. Among them, two were grown in two systems: with and without support. Among the genotypes, there were eleven hybrids and a variety (Table 1 ). Six replications were used, containing ten plants per genotype, spaced 0.5 meters between plants and 2.0 meters between rows. Four plants from each plot were used for the evaluations. In 2018 (summer-autumn), the experimental design was randomized blocks, with twelve genotypes, nine hybrids (Among them, two were grown in two systems, with and without support) and a variety (the Portinari hybrid was not grown in 2016 because there was no seedling emergence) and four replications, containing ten plants per plot, spaced 0.5 meters between plants and four meters between rows. Four plants from each plot were used for the evaluations. The genotypes evaluated are shown in Table 1.

\subsection{Experiment installation and conduction}

Seeds of ten hybrids, in the years 2016 and 2018, and a variety were sown in polystyrene trays containing 4.2 liters of a substrate, composed of the pine tree, coconut fiber, vermiculite, rice husks, and nutrients. The seeds were covered with vermiculite, and the trays were taken to the germination chamber, at $25.5{ }^{\circ} \mathrm{C}$ and $85 \%$ of relative air humidity for 72 hours. 
Table 1. Description of thirteen genotypes, eleven hybrids, and a variety of tomato.

\begin{tabular}{llll}
\hline Genotype & Growth habit & Conduction & Company \\
\hline Ap 533 & Determinate & Unsupported & Seminis \\
HM7885 & Determinate & Unsupported & Agristar-topseed \\
N901 & Determinate & Unsupported & Nunhemes \\
Gabrielle* & Determinate & Unsupported & Hazera seeds \\
Gabrielle & Determinate & Supported & Hazera seeds \\
Thaíse* & Determinate & Unsupported & Feltrin \\
Thaíse & Determinate & Supported & Feltrin \\
Equatorial & Determinate & Supported & Agrocinco \\
Asti & Indeterminate & Supported & Hortivale \\
Carrara & Indeterminate & Supported & Hortivale \\
Dominador & Indeterminate & Supported & Agristar-topseed \\
Santa Cruz Kada** & Indeterminate & Supported & Feltrin \\
BRS Portinari*** & Indeterminate & Supported & Agrocinco \\
\hline
\end{tabular}

* grown without support, ** variety, $* * *$ was not grown in the second cultivation

The seedlings were produced in the commercial nursery Vivati Abadia - GO (Vale do Tietê nursery). The transplant to the field took place at 39 days in 2016 and 35 days in 2018. The seedlings were transplanted to an area where the soil was plowed, and seedbeds were formed, fertilized, and watered.

The local soil is classified as a Latossolo Vermelho distrófico, with the following physical and chemical characteristics: clayey texture, with $486 \mathrm{~g} \mathrm{~kg}^{-1}$ of sand, 100 $\mathrm{g} \mathrm{kg}^{-1}$ of silt, $414 \mathrm{~g} \mathrm{~kg}^{-1}$ of clay, $\mathrm{pH}-\mathrm{CaCl}_{2}: 6.5$, P-Mehlich: $21.2 \mathrm{mg} / \mathrm{dm}^{3}, \mathrm{~K}: 57 \mathrm{mg} / \mathrm{dm}^{3}$, Ca: $5.2 \mathrm{mg} / \mathrm{dm}^{3}, \mathrm{Mg}: 0.8$ cmol $/ \mathrm{dm}^{3}, \mathrm{H}+\mathrm{Al}: 1.4 \mathrm{cmol}_{\mathrm{c}} / \mathrm{dm}^{3}$, and organic matter: $2.1 \%$. The fertilization was carried out according to the crop recommendation and the results of soil chemical analysis. $\mathrm{CO}\left(\mathrm{NH}_{2}\right), \mathrm{P}_{2} \mathrm{O}_{5}$, and $\mathrm{KNO}_{3}$ were applied to the soil and incorporated. Fertigation with calcium and boron was performed weekly after the beginning of flowering. Fertilization was carried out, aiming at the productivity of $100 \mathrm{t} / \mathrm{ha}$, according to the $5^{\text {th }}$ Approach to the State of Goiás (Soil Fertility Commission of Goiás, 1988).

The drip irrigation was carried out, with emitters spaced $0.30 \mathrm{~m}$ apart and flow with daily variation from 3 to $30 \mathrm{~mm}$. The soil was covered with mulching plastic, black and white, with the white side facing up. For disease control, preventive management was carried out with the application of fungicides registered for the tomato crop. The pest management was carried out when there were insects in the experimental area in an amount that would cause damage to the crop. The hybrids and the variety were conducted with and without support (Table 1). Plastic strips were used to conduct the supported hybrids. The hybrids with indeterminate growth habit were conducted with two stems, and the hybrids with determined growth habit were conducted with the total number of stems.

\subsection{Evaluations}

In both crops, four harvestings were performed: in 2016, at 72, 82, 97, and 105 days after transplanting (DAT), and in 2018, at 81, 87, 97, and 111 days after transplanting (DAT), respectively. The ripe fruits per plot, from four plants, were harvested and taken to the laboratory, where the evaluations of the total number of fruits (TNF), total production (TP) $\mathrm{kg} / \mathrm{plant}$, commercial fruit production (CFP), non-commercial fruit production (NCFP), number of commercial fruits (NCF), and number of non-commercial fruits (NNCF) were performed, for the harvestings at 82 and 97 DAT, in 2016, and 87 and 97 DAT, in 2018. The fruit collections were from the second and third harvestings since the genotypes have different maturation cycles. The fruits were considered non-commercial when they showed damage caused by pests (borer and/or moths) and other defects (open locule, apical rot, sunburn, and rotten). For weighing the fruits, a digital scale was used, and the results were expressed in $\mathrm{kg}_{\text {plant }}{ }^{-1}$.

The classification of the fruits was carried out with the aid of a digital caliper, measuring the longitudinal (from the peduncle to stigma) and transversal (equatorial region of the fruit) diameters of all commercial fruits. The commercial fruits were divided into two groups: oblong (longitudinal diameter larger than the transversal) and round (longitudinal diameter smaller than the transversal). The oblong hybrids and variety (Ap533, Asti, Carrara, Equatorial, Gabrielle, HM7885, N901, and Santa Cruz Kada) were divided into classes, according to the transversal diameter, in large $(>60 \mathrm{~mm})$, medium (> 50 to $60 \mathrm{~mm}$ ), and small (> 40 to $50 \mathrm{~mm}$ ). The round hybrids (Portinari, Thaise, and Dominador) were divided into classes, according to the transversal diameter: giant (> 100mm), large (> 80 to $100 \mathrm{~mm}$ ), medium (> 65 to 80 $\mathrm{mm}$ ), and small (>50 to $65 \mathrm{~mm}$ ). The classification was carried out following current legislation, MAARA Ordinance $\mathrm{N}^{\circ}$. 553/95 (Brazil, 1995) and according to the proposal, in Annex XVII, of SARC Ordinance $\mathrm{N}^{\circ}$. 085/02 from MAPA (Brazil, 2002).

In the economic viability assessment, the gross value of production (GVP) and profit were calculated. The GVP was calculated from the product between total 
production (10,000 plants, $\mathrm{t} / \mathrm{ha})$ and average fruit price $\left(\mathrm{R} \$ \mathrm{t} / \mathrm{ha}^{-1}\right)$. Average ton prices in $\mathrm{R} \$$ (reais) were according to the Institute for the Strengthening of Agriculture in Goiás, regarding the years 2016 and 2018. In 2016, the price per ton for table-tomato was $\mathrm{R} \$$ 2277.00 and $\mathrm{R} \$ 220$ for industrial tomato; in 2018, prices were R\$ 2051.00/t for table-tomato and R \$ 200/t for industrial tomato. The total profit was obtained by subtracting from the GVP the total production cost of the hectare (Table 2) (Antunes and Reis, 1998).

Biometric data of the genotypes were subjected to analysis of variance, and the means were grouped by the Scott-Knott test at $5 \%$ probability, with the aid of the Sisvar software (Ferreira, 2014). The calculation of financial data for economic analysis was performed using Microsoft ${ }^{\circledR}$ Office Excel spreadsheets.

Table 2. Summary of the production cost of industrial tomatoes and table-tomatoes for the cultivation in 2016 and 2018.

\begin{tabular}{|c|c|c|c|c|}
\hline \multirow[t]{2}{*}{ PRODUCTION COSTS OF INDUSTRIAL TOMATO } & \multicolumn{2}{|c|}{2016} & \multicolumn{2}{|c|}{2018} \\
\hline & $\mathrm{R} \$ / \mathrm{ha}$ & $\% /$ ha & $\mathrm{R} \$ / \mathrm{ha}$ & $\% / \mathrm{ha}$ \\
\hline \multicolumn{5}{|l|}{ DESCRIPTION EOC } \\
\hline Labor & 337.94 & 2.74 & 1168.94 & 6.02 \\
\hline Mechanical operations & 3453.73 & 28.02 & 5359.21 & 27.58 \\
\hline Fertilizers and correctives & 2394 & 19.42 & 3614.31 & 18.6 \\
\hline Defensive & 3142.53 & 25.49 & 5366.32 & 27.62 \\
\hline Seeds/Seedlings & 1650 & 13.39 & 1995.65 & 10.27 \\
\hline Financial/administrative & 448.50 & 3.64 & 1925.77 & 9.91 \\
\hline \multicolumn{5}{|l|}{ EXPENSES EOC } \\
\hline Pre-planting & 471.84 & 3.83 & 1083.39 & 5.58 \\
\hline Planting & 4317.56 & 35.03 & 5159.73 & 26.56 \\
\hline Crop conduction & 4524.15 & 36.7 & 7489.85 & 38.55 \\
\hline Harvesting & 2564.02 & 20.8 & 3771.46 & 19.41 \\
\hline Financial & 448.5 & 3.64 & 1925.77 & 9.91 \\
\hline TOTAL EOC & 12326.08 & 100 & 19430.2 & 100 \\
\hline Depreciation & 217.63 & 1.58 & 310.57 & 1.46 \\
\hline TOC & 12543.71 & & 19740.77 & \\
\hline Costs of fixed income factors & 1250.62 & & 1497.15 & \\
\hline TOTAL COST & 13794.33 & & 21237.92 & \\
\hline PRODUCTION COSTS OF TABLE- TOMATO & $\mathrm{R} \$ / \mathrm{ha}$ & $\%$ ha & $\mathrm{R} \$ / \mathrm{ha}$ & \%ha \\
\hline Fertilizers (soil and leaf), correctives & 14840.65 & 14.1 & 14840.65 & 14.1 \\
\hline Defensive, adjuvant, inductors, regulators & 16950.36 & 16.2 & 16950.36 & 16.2 \\
\hline Seeds/Seedlings & 6127.00 & 5.8 & 6127.00 & 5.8 \\
\hline Mechanical operations & 4394.48 & 4.2 & 4394.48 & 4.2 \\
\hline Infrastructure, Irrigation & 7011.67 & 6.7 & 7011.67 & 6.7 \\
\hline Labor & 31676.93 & 30.2 & 31676.93 & 30.2 \\
\hline Utilities and general expenses & 5333.46 & 5.1 & 5333.46 & 5.1 \\
\hline Financial, administrative & 12002.63 & 11.4 & 12002.63 & 11.4 \\
\hline CARP & 6581.02 & 6.3 & 6581.02 & 6.3 \\
\hline TOTAL COST & 104918.2 & & 104918.2 & \\
\hline
\end{tabular}

EOC (effective operating cost), TOC (total operating cost), data collection 2016 and 2018, population 33000 plants/ha. The production cost of industrial tomatoes, according to the Institute for the Strengthening of Agriculture in Goiás - IFAG (IFAG, 2018). CARP (Annual Cost of Asset Recovery), data collection 2016. Population 10,000 plants/ha, cost of tomato production according to the Center for Advanced Studies on Applied Economics - CEPEA (Deleo, 2017).

\section{Results and Discussion}

In the two years of cultivation, there was a significant difference between hybrids and varieties concerning total production and the number of fruits. In the first cultivation (2016), the hybrids that obtained the highest production per plant were: Gabrielle, without support, with $6,010 \mathrm{~kg}$ per plant, Thaise, without support, with $5,529 \mathrm{~kg}$, and N901, with $5,003 \mathrm{~kg}$. The higher production of these plants may be associated with the fact that they have not been pruned, thus providing a greater number of branches and, consequently, a greater number of fruits when compared with the supported plants (Oliveira et al., 1995).

In the second cultivation (2018), the Dominador and Thaise hybrids were those with the highest production, with 4.109 and $3.961 \mathrm{~kg}$ per plant, respectively. The better performance of these hybrids may be associated with their vitality and resistance to diseases, thus contributing to their higher productivity, since the period of this cultivation, summer-autumn, has a higher rainfall and higher susceptibility to diseases, such as leaf diseases, that unsupported plants can accelerate ripening and, 
consequently, increase the number of unviable fruits for fresh consumption (Quezado-Duval et al., 2014) (Table 3).

Regarding the number of fruits per plant, there are significant differences between genotypes. In 2016, the hybrid AP533 obtained 77 fruits, which is the highest value among all genotypes; however, it does not differ statistically from the Asti, Dominador, Gabrielle unsupported, HM7885, and N901 hybrids. In 2018, the largest number of fruits was observed in the N901 and HM7885 hybrids, with 66 and 65 fruits per plant, respectively. About the total number of fruits (TNF), in 2016, the lowest total number of fruits was observed in Portinari, Carrara, Gabrielle supported, Santa Cruz Kada, Thaise supported, Equatorial, and Thaise unsupported. In 2018, the Santa Cruz Kada variety, with an average of 27 fruits per plant, was the one with the lowest performance (Table 3).

The Santa Cruz Kada variety, in the two years of cultivation, had the lowest total mass per plant, with $2.623 \mathrm{~kg}$ in 2016 and $1.612 \mathrm{~kg}$ in 2018 , accompanied by a low number of fruits. This performance may be associated with its low resistance to diseases compared to cultivated hybrids (Seminis, 2018; Agristar, 2018; Nunhemes, 2018; Hazera, 2018; Feltrin, 2018; Agrocinco, 2018; Hortivale, 2018) (Table 3).

The higher production of fruits, possibly, is associated with the fact that there was not pruning of secondary stems, and the plants present higher rusticity. Thus, these plants with a higher number of stems, consequently, will have a higher number of fruits. Hybrids that have greater rusticity will produce more fruits, as they can stand out from the broad spectrum of pathogens that the tomato has as a host, besides to physiological disorders (Oliveira et al., 1995), collaborating with the observations of Carvalho and Tessarioli Neto (2005), Wamser et al. (2008) and Wamser et al. (2009), that there is an influence of the number of stems and plant density in the production for supported plants.

About total productivity and the total number of fruits evaluated with the Scott-Knott test $(\mathrm{p} \leq 0.05)$, in 2016, there was a statistical difference for all materials, which obtained a higher overall average than in 2018, with $4.156 \mathrm{~kg}$ for weight and 50.509 for the number of fruits (Table 3). The superior production in 2016, supposedly, is due to the better climatic condition, a lower relative humidity of the air, and less susceptibility to leaf diseases in comparison to the second year of cultivation.

In the second and third harvestings, in both years, there were significant differences between the weight of non-commercial and commercial fruits, thus demonstrating higher adaptability to the experimental environmental conditions in each period. In the 2016 cultivation, the N901 and AP533 hybrids, with 14,292 and 12,917 fruits, respectively, presented the largest number of non-commercial fruits. These hybrids were cultivated without the support and, consequently, the leaf area was more exposed to humidity, favoring diseases, and making unfeasible the commercialization of fruits. However, despite the greater number of non-commercial fruits, these hybrids also showed a greater number of total fruits, with values similar to Gabrielle and HM7885 without support (Table 4). Hybrids with a higher number of fruits contribute more to productivity, since, to obtain a high tomato production, a high number of fruits per growth area is necessary (Sandri et al., 2002).

The Portinari hybrid had a high mass of noncommercial fruits, with $0.898 \mathrm{~kg}$, not differing from the AP533, Asti, Gabrielle, and Thaise hybrids, which were cultivated without support. Although the Gabrielle hybrid, without support, belongs in the group of hybrids with the highest weight of non-commercial fruits, this genotype also obtained a high weight of commercial fruits, with $1.881 \mathrm{~kg}$ per plant (Table 4).

Table 3. Total production per plant (kg plant-1) and the total number of fruits per plant, in the years 2016 and 2018 . TP (total production) and TNF (total number of fruits).

\begin{tabular}{|c|c|c|c|c|}
\hline \multirow{2}{*}{ Genotype } & \multicolumn{2}{|c|}{2016} & \multicolumn{2}{|c|}{2018} \\
\hline & $\mathrm{TP}(\mathrm{kg})$ & TNF & $\mathrm{TP}(\mathrm{kg})$ & TNF \\
\hline $\mathrm{AP}$ & $4.685 \mathrm{c}$ & $76.083 \mathrm{~b}$ & $2.656 \mathrm{~b}$ & $52 \mathrm{c}$ \\
\hline ASTI & $3.348 \mathrm{a}$ & $62.308 \mathrm{~b}$ & $2.115 \mathrm{a}$ & $37 \mathrm{~b}$ \\
\hline Carrara & $3.645 \mathrm{~b}$ & $33.433 \mathrm{a}$ & $2.736 \mathrm{~b}$ & $40 \mathrm{~b}$ \\
\hline Dominador & $3.663 \mathrm{~b}$ & $54.367 \mathrm{~b}$ & $4.109 \mathrm{~d}$ & $41 \mathrm{~b}$ \\
\hline Equatorial & $3.640 \mathrm{~b}$ & $43.800 \mathrm{a}$ & $3.186 \mathrm{c}$ & $46 \mathrm{~b}$ \\
\hline Gabrielle & $4.368 \mathrm{~b}$ & $40.533 \mathrm{a}$ & $3.213 \mathrm{c}$ & $39 \mathrm{~b}$ \\
\hline Gabrielle* & $6.010 \mathrm{~d}$ & $54.667 \mathrm{~b}$ & $3.132 \mathrm{c}$ & $43 \mathrm{~b}$ \\
\hline $\mathrm{HM}$ & $3.947 \mathrm{~b}$ & $56.125 \mathrm{~b}$ & $2.688 \mathrm{~b}$ & $65 \mathrm{~d}$ \\
\hline N901 & $5.003 \mathrm{c}$ & $73.083 \mathrm{~b}$ & $2.368 \mathrm{~b}$ & $66 \mathrm{~d}$ \\
\hline Santa Cruz & $2.623 \mathrm{a}$ & $41.541 \mathrm{a}$ & $1.612 \mathrm{a}$ & $27 \mathrm{a}$ \\
\hline Thaise & $4.153 \mathrm{~b}$ & $41.825 \mathrm{a}$ & $3.961 \mathrm{~d}$ & $36 \mathrm{~b}$ \\
\hline Thaise* & $5.529 \mathrm{~d}$ & $46.267 \mathrm{a}$ & $2.999 \mathrm{c}$ & $36 \mathrm{~b}$ \\
\hline Portinari & $3.292 \mathrm{a}$ & $29.350 \mathrm{a}$ & - & - \\
\hline $\mathrm{CV}(\%)$ & 16.92 & 39.49 & 27.50 & 28.46 \\
\hline Average & 4.156 & 50.307 & 2.898 & 44.146 \\
\hline
\end{tabular}

Means followed by the same letter, in the column, belong to the same group by the Scott-Knott test ( $\mathrm{p} \leq 0.05)$. 
Table 4. Production and the average number of commercial and non-commercial fruits, in the second and third harvesting, in 2016. CFP (commercial fruit production, kg/plant), NCFP (non-commercial fruit production, kg/plant), NCF (number of commercial fruits), and NNCF (number of non-commercial fruits).

\begin{tabular}{lcccc}
\hline Genotype & \multicolumn{2}{c}{ NNCF } & NCFP & CFP \\
\cline { 2 - 4 } & \multicolumn{2}{c}{ Second harvesting } & $0.806 \mathrm{~b}$ & $1.576 \mathrm{~b}$ \\
\hline AP & $12.917 \mathrm{~d}$ & $17.875 \mathrm{c}$ & $0.631 \mathrm{a}$ & $0.826 \mathrm{a}$ \\
ASTI & $7.208 \mathrm{~b}$ & $7.208 \mathrm{a}$ & $0.892 \mathrm{~b}$ & $0.847 \mathrm{a}$ \\
Carrara & $8.167 \mathrm{~b}$ & $5.833 \mathrm{a}$ & $0.678 \mathrm{a}$ & $0.931 \mathrm{a}$ \\
Dominador & $5.375 \mathrm{a}$ & $5.708 \mathrm{a}$ & $0.758 \mathrm{a}$ & $1.308 \mathrm{~b}$ \\
Equatorial & $8.500 \mathrm{~b}$ & $12.000 \mathrm{~b}$ & $0.727 \mathrm{a}$ & $1.500 \mathrm{~b}$ \\
Gabrielle & $8.333 \mathrm{~b}$ & $13.125 \mathrm{~b}$ & $0.852 \mathrm{~b}$ & $1.881 \mathrm{c}$ \\
Gabrielle* & $11.375 \mathrm{c}$ & $19.250 \mathrm{c}$ & $0.606 \mathrm{a}$ & $1.215 \mathrm{~b}$ \\
HM & $9.917 \mathrm{c}$ & $17.000 \mathrm{c}$ & $0.694 \mathrm{a}$ & $1.446 \mathrm{~b}$ \\
N901 & $14.292 \mathrm{~d}$ & $24.458 \mathrm{~d}$ & $0.898 \mathrm{~b}$ & $1.230 \mathrm{~b}$ \\
Portinari & $6.917 \mathrm{~b}$ & $8.542 \mathrm{a}$ & $0.654 \mathrm{a}$ & $0.722 \mathrm{a}$ \\
Santa Cruz & $8.708 \mathrm{~b}$ & $7.125 \mathrm{a}$ & $0.588 \mathrm{a}$ & $1.474 \mathrm{~b}$ \\
Thaise & $4.167 \mathrm{a}$ & $8.750 \mathrm{a}$ & $0.894 \mathrm{~b}$ & $1.418 \mathrm{~b}$ \\
Thaise* & $7.417 \mathrm{~b}$ & $9.792 \mathrm{~b}$ &
\end{tabular}

Means followed by the same letter, in the column, belong to the same group by the Scott-Knott test $(\mathrm{p} \leq 0.05)$.

In the second cultivation year, in 2018, the highest number of non-commercial fruits was observed in the AP533 and N901 hybrids, 12,125 and 11,688 fruits, respectively. The N901 hybrid also produced the highest number of commercial fruits, with 18,375 fruits. The Dominador hybrid, in this same cultivation, presented a higher weight of non-commercial fruits, with $0.8433 \mathrm{~kg}$, not differing statistically from the AP533, Carrara, Equatorial, Gabrielle, and Thaise hybrids, cultivated with and without support. The highest weight of commercial fruits was found in the Thaise hybrid, with $1.393 \mathrm{~kg} / \mathrm{plant}$ (Table 5).

Unsupported plants are more susceptible to produce non-commercial fruits since the formation of a microclimate with higher humidity provides greater chances of attack by pests and diseases; thus, the use of mulching avoid the contact between the fruits and soil and, consequently, contributes to increasing the value of fruits (Rodrigues et al., 2014; Hirata, 2015). However, this factor was minimized in the experiment when using mulching, which increases the local temperature, protects the fruits from direct contact with the soil, in addition to helping to reduce the incidence of weeds, pests, and diseases.

The tomato fruit classification is performed according to the current legislation - MAARA Ordinance $n^{\circ} .553 / 95$ and by the proposal, in Annex XVII, of SARC Ordinance $n^{\circ}$. 085/02 from MAPA. In the first year of cultivation, and only in the second harvesting, the Carrara hybrid had more than $50 \%$ of fruits considered large. The hybrids, Gabrielle (unsupported and supported), Santa Cruz, Equatorial, Dominador, Thaise (unsupported and supported), and Portinari, had more than 50\% of the fruits classified as medium in the second and third harvesting. The fruits of AP533, HM7885, and N901 hybrids were classified, in both harvests, as small (Brasil, 1995; Brasil, 2002). This result was already foreseen since these hybrids have characteristics of producing smaller fruits since they are destined exclusively for industrial processing, and the smaller fruit size is not considered a defect in this segment (Alvarenga et al., 2013; Sediyama et al., 2003) (Figures 1 and 2).

Table 5. Production and the average number of commercial and non-commercial fruits, in the second and third harvesting, in 2018. CFP (commercial fruit production, kg/plant), NCFP (non-commercial fruit production, $\mathrm{kg} / \mathrm{plant}$ ), NCF (number of commercial fruits), and NNCF (number of non-commercial fruits).

\begin{tabular}{lllll}
\hline Genotype & NNCF & NCF & NCFP & CFP \\
\cline { 2 - 5 } & Second harvesting & & Third harvesting & \\
\hline AP & $12.125 \mathrm{~b}$ & $14.125 \mathrm{c}$ & $0.589 \mathrm{~b}$ & $0.959 \mathrm{c}$ \\
Asti & $8.250 \mathrm{a}$ & $7.250 \mathrm{~b}$ & $0.515 \mathrm{a}$ & $0.690 \mathrm{~b}$ \\
Carrara & $8.000 \mathrm{a}$ & $7.438 \mathrm{~b}$ & $0.659 \mathrm{~b}$ & $0.823 \mathrm{~b}$ \\
Dominador & $6.438 \mathrm{a}$ & $4.563 \mathrm{a}$ & $0.843 \mathrm{~b}$ & $0.768 \mathrm{~b}$ \\
Equatorial & $8.563 \mathrm{a}$ & $9.750 \mathrm{~b}$ & $0.650 \mathrm{~b}$ & $0.884 \mathrm{~b}$ \\
Gabrielle & $8.250 \mathrm{a}$ & $11.563 \mathrm{c}$ & $0.680 \mathrm{~b}$ & $1.123 \mathrm{c}$ \\
Gabrielle* & $7.250 \mathrm{a}$ & $13.688 \mathrm{c}$ & $0.445 \mathrm{a}$ & $1.151 \mathrm{c}$ \\
HM & $9.500 \mathrm{a}$ & $14.000 \mathrm{c}$ & $0.377 \mathrm{a}$ & $0.748 \mathrm{~b}$ \\
N901 & $11.688 \mathrm{~b}$ & $18.375 \mathrm{~d}$ & $0.418 \mathrm{a}$ & $0.939 \mathrm{c}$ \\
Santa Cruz & $7.000 \mathrm{a}$ & $4.563 \mathrm{a}$ & $0.524 \mathrm{a}$ & $0.332 \mathrm{a}$ \\
Thaise & $7.000 \mathrm{a}$ & $10.125 \mathrm{~b}$ & $0.721 \mathrm{~b}$ & $1.393 \mathrm{~d}$ \\
Thaise* & $8.563 \mathrm{a}$ & $5.500 \mathrm{a}$ & $0.715 \mathrm{~b}$ & $0.596 \mathrm{~b}$ \\
\hline
\end{tabular}

Means followed by the same letter, in the column, belong to the same group by the Scott-Knott test $(\mathrm{p} \leq 0.05)$. 
In 2018, the Dominador and Thaise hybrids, in the second and third harvesting, had more than $50 \%$ of their fruits classified as medium, whereas, the fruits of the hybrids, AP533, Asti, Gabrielle (unsupported and supported), N901, and Thaise (unsupported and supported), and the Santa Cruz variety had more than $50 \%$ of their fruits classified as small (Figures 3 and 4).

The gross value of production $(\mathrm{GVP}=$ production (t/ha) $x$ average price $(\mathrm{R} \$ / \mathrm{t} / \mathrm{ha})$ ) of tomatoes in 2016 was higher than 2018 for hybrids and varieties, except for the Dominador hybrid (Figure 5). This difference in GVP is justified by the higher volume of fruits produced in 2016 (hybrids and varieties with indeterminate growth habit, supported) and the higher production cost in the second year for unsupported hybrids. Production costs of unsupported hybrids were R \$ $13,794.33$ in 2016, and R \$ $21,342.10$ in 2018 . In other words, the costs related to

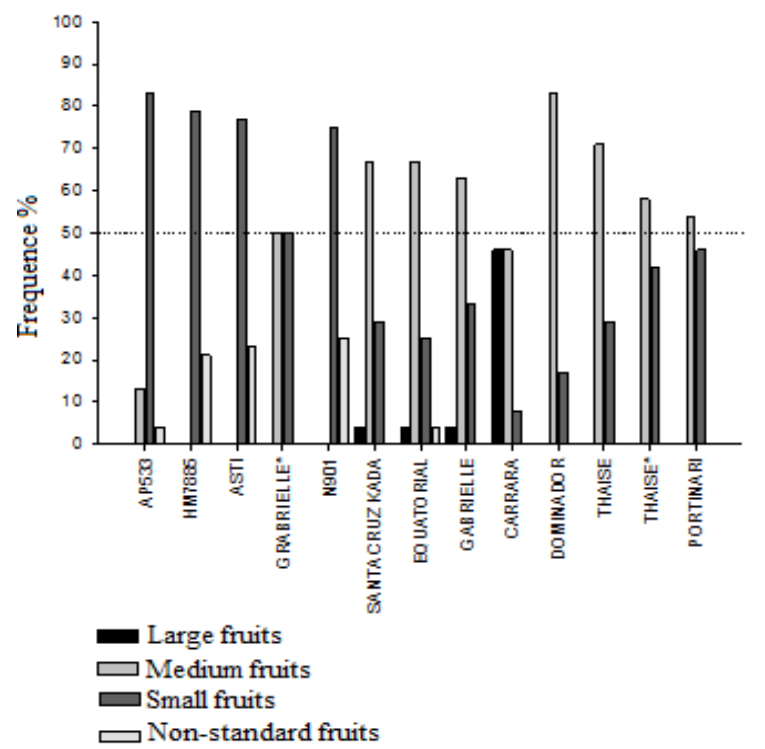

Figure 1. Classification of oblong and round tomato fruits in the second harvest of the 2016 cultivation.

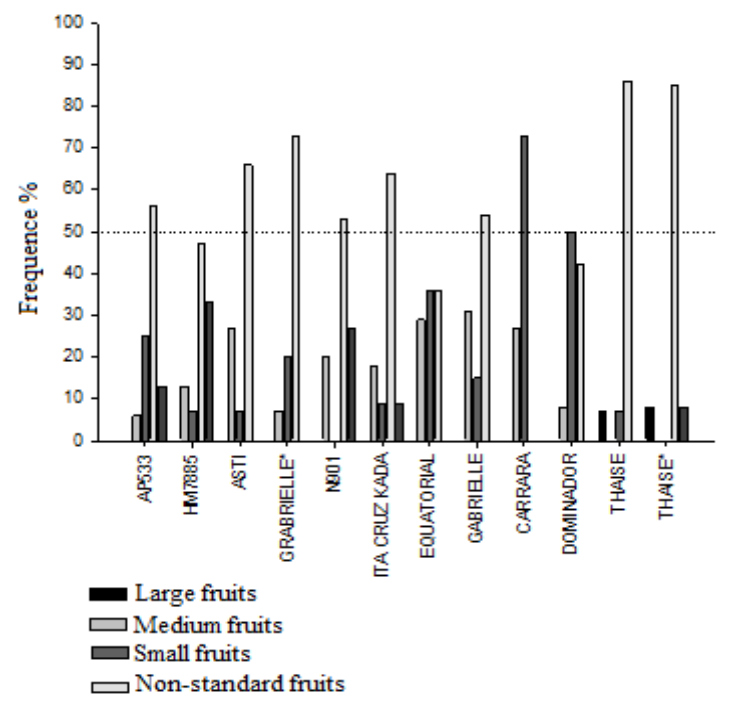

Figure 3. Classification of oblong and round tomato fruits in the second harvest of the 2018 cultivation.
2018 were $64.63 \%$ higher than those of 2016 , a factor that contributed to the highest GVP in that year.

The table-tomato, with a cost of $\mathrm{R} \$ 104,918.00$, led to a negative profit in the two periods analyzed for all supported hybrids and variety. The highest production cost for supported plants is mainly related to labor. Researchers found that in the conventional system of tomato production in a protected environment, labor was responsible for $21.3 \%$ of the production cost, which is the factor that most raised the production cost (Rezende et al., 2003). The higher demand for labor is one of the factors that contribute to raising the production cost of the supported cultivation, due to the crop management that includes: pruning, fruit thinning, stem conduction, removal of old leaves to reduce the incidence of diseases foliar, phytosanitary treatment, among others (Alvarenga et al., 2013).

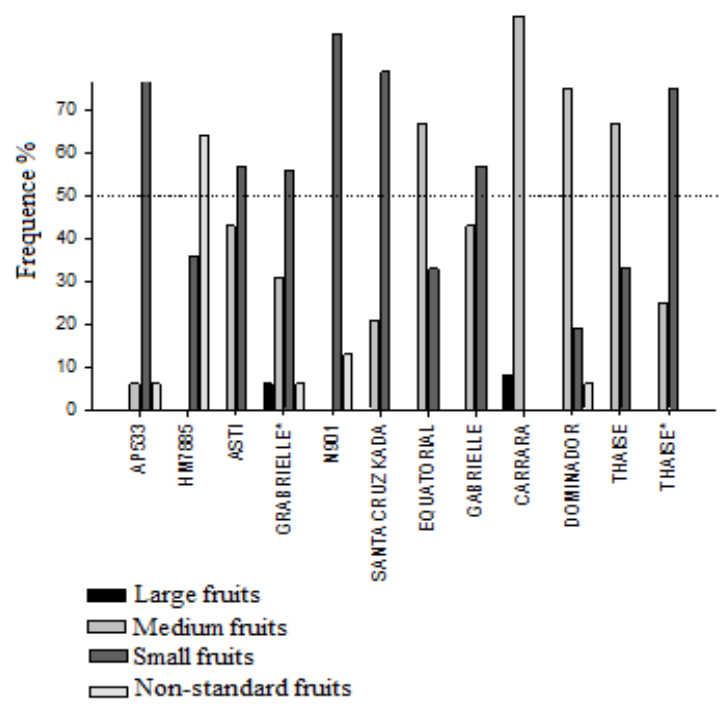

Figure 2. Classification of oblong and round tomato fruits in the third harvest of the 2016 cultivation.

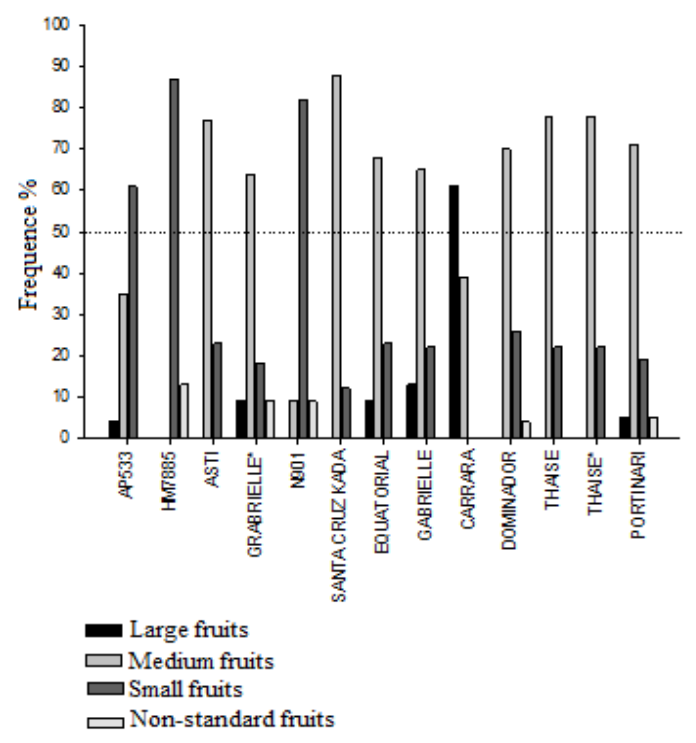

Figure 4. Classification of oblong and round tomato fruits in the third harvest of the 2018 cultivation. 


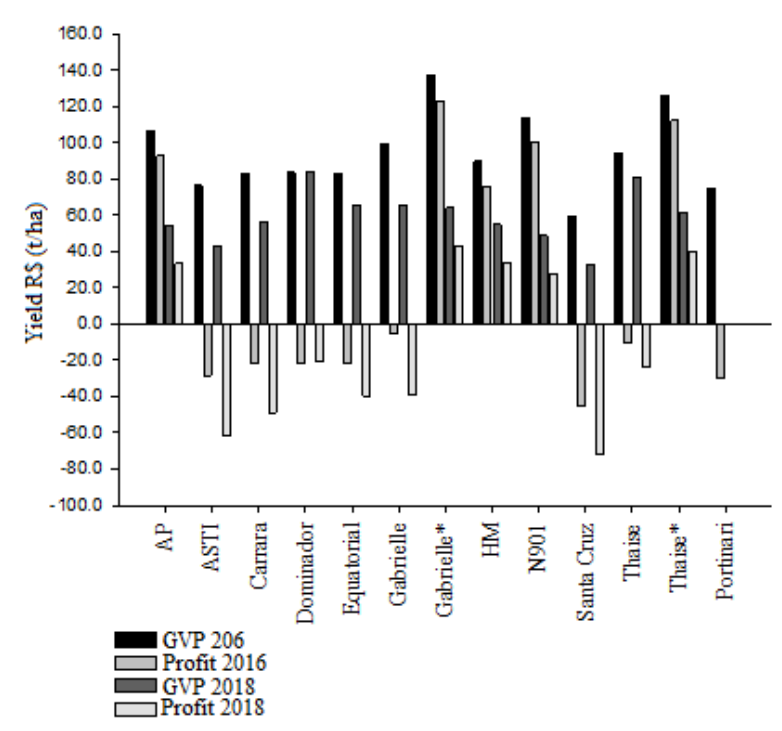

Figure 5. Indicator od production, GVP (gross value of production) and profit for tomato hybrids and varieties grown in the Goiânia-GO, in 2016 and 2018.

According to the Center for Advanced Studies on Applied Economics (CEPEA), in summer production 2017/2018, the labor for the table-tomato production represented $30.2 \%$ of production costs in Minas Gerais. In São Paulo, it represented 34\%, in 2016 (Deleo et al., 2016). On the other hand, in Goiás, labor represented $2.74 \%$ of production costs of cultivation of industrial tomato in 2016 and $6.04 \%$ in 2018 . According to the IFAG (2018), the lower labor cost in cultivated tomatoes destined for the industry is due to the lower demand for crop management.

\section{Conclusions}

Hybrids with a determined growth habit and conducted without support are a productive and profitable alternative for the commercialization of tomatoes intended for fresh consumption. The economic viability of hybrids grown without support proved to be superior to those supported.

However, the Gabrielle and Thaise hybrids (without support), in 2016, the climatic period considered dry, presented the best cost-benefit ratio. In 2018, in cultivation carried out in the rainy season, the best costbenefit ratio was observed in the Dominador and Thaise hybrids, both supported.

\section{Bibliographic References}

Agristar Topseed, 2018. http://agristar.com.br/topseedpremium/tomate-industrial-hibrido/hmx-7885-f1/3411 (acessado 20 de junho de 2018).
Agrocinco Seeds of 2018. http://www.agrocinco.com.br/2013/produtos.asp?id=1 (acessado 20 de junho de 2018).

Alvarenga, M.A.R., Lima, L.A., Faquin, V., Pereira, G.M., 2013. Tomate: produção em campo, casa de vegetação e hidroponia, segunda ed. UFLA, Lavras.

Antunes, L.M., Reis, L.R., 1998. Gerência agropecuária: análise de resultados. Guaíba, Agropecuária.

Brasil, 1995. Ministério da Agricultura do Abastecimento e da Reforma Agrária. Portaria n 553 de 30 de agosto de 1995. Dispõe sobre a Norma de Identidade, Qualidade, Acondicionamento e Embalagem do Tomate in natura, para fins de comercialização e revoga as especificações de Identidade, Qualidade, Acondicionamento e Embalagem do Tomate, estabelecidas pela Portaria ${ }^{\circ}$. 76, de 25 de fevereiro de 1975. Diário Oficial da República Federativa do Brasil, Brasília, 8 p.

Brasil, 2002. Ministério da Agricultura do Abastecimento e da Reforma Agrária. Portaria 285 SARC n ${ }^{\circ} 085$ de 06 março de 2002. Propõe o regulamento técnico de identidade e qualidade para classificação do tomate. Diário Oficial da república Federativa do Brasil, 8 p.

Carvalho, L.A., Tessarioli Neto, J., 2005. Produtividade de tomate em ambiente protegido, em função do espaçamento e número de ramos por planta. Horticultura Brasileira, 23(4), 986-989.

Comissão de Fertilidade de Solos de Goiás, 1988. Recomendações de corretivos e fertilizantes para Goiás. $5^{\text {a }}$ aproximação. Goiânia: UFG, Emgopa (Informativo Técnico, 10 p.).

Deleo, J.P.B, 2017. Gestão sustentável, quanto custa produzir, alface, cenoura e tomate no Brasil. Hortifruti Brasil, 168, 1019.

Deleo, J.P.B., Junior, J.S.B., Paranhos, G.G., 2016. Tomate gestão sustentável: Custo para se produzir um hectare de tomate ultrapassa R\$ 100mil. Hortifruti Brasil, 157, 10-24.

Factor, T.L., Lima, J.R., Purqueiro, L.F.V., Branco, R.F., Blat, S.F., Araújo, J.A.C., 2009. Produtividade e qualidade de tomate em função da cobertura do solo e planta com agrotêxtil. Horticultura Brasileira, 27(2), 606-612.

FAOSTAT. Organização das Nações Unidas para a Agricultura e a Alimentação, 2018. http://www.fao.org/faostat/en/\#home (acessado 22 de junho, 2018).

Feltrin

Sementes, 2018. https://www.sementesfeltrin.com.br/Produto (acessado 20 de junho 2018).

Ferreira, D.F., 2014. Sisvar: a Guide for its bootstrap procedures in multiple comparisons. Ciência e Agrotecnologia, Lavras, 38(2) 109-112.

Filgueira, F.A.R., 2003. Solanáceas: agrotecnologia moderna na produção de tomate, batata, pimentão, pimenta, berinjela e jiló. Lavras, UFLA. 
Hazera Seeds, 2018. https://www.hazera.com.br/product/gabryelle/ (Acessado 20 de junho de 2018).

Hirata, A.C.S., 2015. Mulching em tomate facilita o controle de ervas daninhas. Agência Paulista de Tecnologia dos Agronegócios (APTA). Revista Campo \& Negócios. http://www.revistacampoenegocios.com.br/mulching-emtomate-facilita-o-controle-de-ervas-daninhas/ (acessado 18 de junho de 2018).

Hortivale, 2018. http://www.hortivale.com.br (acessado de 20 de junho 2018).

IFAG. Instituto para o Fortalecimento da Agropecuária de Goiás, 2018. http://ifag.org.br/custos-de-producao (acessado 26 de junho de 2018).

Lifschitz, E., Ayre, B.G., Eshed, Y., 2014. Florigen and antiflorigen-a systemic mechanism for coordinating growth and termination in flowering plants. Frontiers in Plant Science, 5, 465 .

Margarido, M.A., Kato, H.T., Ueno, L.H., 1994. Aplicação da metodologia BoxJenkins na análise da transmissão de preços no mercado de tomate no Estado de São Paulo. Estudos Econômicos, 24(3), 405-32.

Navarrete, M., Jeannequin, B., 2000. Effect of frequency of axillary bud pruning on vegetative growth and fruit yield in greenhouse tomato crops. Scientia Horticulturae, 86(3), 197210.

Nunhemes, 2018

http://www.nunhems.com.br/www/nunhemsinternet.nsf/id/ (acessado 18 de junho de 2018).

Oliveira, V.R., Campos J.P., Fontes, P.C.R., Reis F.P., 1995. Efeito do número de hastes por planta e poda apical na produção classificada de frutos de tomateiro (Lycopersicon esculentum Mill). Ciência e Prática, 19(4), 414-419.

Pagliuca, L.G., Deleo, J.P.B., Boteon, M., Mueller, S., Valmorbida, J., 2017. Análise da economicidade da produção de tomate de mesa em diferentes escalas de produção na região de Caçador/SC. Custos e Agronegócio, 13(ed. esp.), 227-243.

Piotto, F.A., Peres, L.E.P., 2012. Base genética do hábito de crescimento e florescimento em tomateiro e sua importância na agricultura. Ciência Rural, 42(11), 1941-1946.

Pnueli, L., 1998. The SELF-PRUNING gene of tomato regulates vegetative to reproductive switching of sympodial meristems and is the ortholog of CEN and TFL1. Development, 125(11), 1979-1989.
Quezado-Duval, A.M., Nascimento, A.R., Pontes, N.C., Moita, A.W., Assunção, A., Golynski, A., Inoue-Nagata, A.K., Oliveira, R.T., Castro, Y.O., Melo, B.J., 2014. Desempenho de híbridos de tomate para processamento industrial em pressão de begomovirose e de mancha- bacteriana. Horticultura Brasileira, 32(4), 446-452.

Rezende, B.L.A., Cecílio Filho, A.B., Martins, M.I.E.G., 2003. Custo de produção da cultura do tomateiro, em cultivo protegido, em Jaboticabal-SP. Horticultura Brasileira, 21(2).

Rick, C.M., 1978. The tomato. Scientific American, 239(2), 7687.

Rodrigues, G.S.O., Negreiros, M.Z., Lopes, W.A.R., Grangeiro, L.C., Lima, J.S.S., 2014. Growth and partitioning of assimilates in Tomato trees due to the different kinds of mulching. Caatinga, 27(2), 10-17.

Sandri, M.A., Adriolo, J.L., Witter, M., Dal Ross, T., 2002. Hight density of defoliated tomato plants inprotected cultivation and effects on development of trusses and fruits. Horticultura Brasileira, 20(3), 485-489.

Sediyama, M.A.N., Fontes, P.C.R., Silva, D.J.H., 2003. Práticas culturais adequadas ao tomateiro. Informe Agropecuário, 24(219), 19-25.

Seminis Vegetable $\quad$ Seeds, 2018. http://www.seminis.com.br/Produtos/ap533/427 (acessado 22 de junho de 2018).

UFG/EA. Universidade Federal de Goiás/Escola de Agronomia, 2018. Dados meteorológicos: Estação Convencional da Escola de Agronomia. https://www.agro.ufg.br/p/7944-estacao-agrometeorologica (acessado 15 de junho 2018).

Wamser, A.F., Becker, W.F., Santos, J.P., Muller, S., 2008. Influência do Sistema de condução do tomateiro sobre a incidência de doenças e insetos-praga. Horticultura Brasileira, 26(2), 180-185.

Wamser, A.F., Muller, S., Becker, W.F., Santos, J.P., Suzuki, A., 2009. Espaçamento entre plantas e cachos por haste no tutoramento vertical do tomateiro. Horticultura Brasileira, 27(4), 565-570.

Zsogon, A., Vicente, M.H., Reartes, D.S., Peres, L.E.P., 2017. Understanding and improving water-use efficiency and drought resistance in tomato. Achieving sustainable cultivation of tomatoes (Burleigh dodds series in agricultural science), S.1, s.n. 